\title{
Urgensi Bimbingan Karier di Perguruan Tinggi \\ Untuk membantu Kesiapan mahasiwa Tahun Akhir Memasuki Dunia Kerja
}

\author{
Hermi Pasmawati*
}

\begin{abstract}
The final year students are individuals who are in transition from career stages or stages, namely the transition from the pre-occupation to the occupation stage, or starting from the period of education to the working period. This stage includes a difficult period, after the preor post-occupation period, because this period or period is faced with real phenomena. For this reason, students need to be equipped with insight, understanding and difficulty to enter the workforce starting from the stage, knowledge of job information and making decisions on the fields of work to be occupied, to the readiness of self-adjustment to ethics and work culture and self-development after work. doing this can be done with guidance that can be implemented with a variety of services and counseling, namely through information services, information, individual counseling services and group guidance services.
\end{abstract}

Keyword : career guidance, readiness to world of work

\section{Pendahuluan}

Bimbingan karier di perguruan tinggi merupakan salah satu poin penting yang menjadi kreteria penilaian akreditasi perguruan tinggi, poin ini tertuang di bagian Standar tiga tentang mahasiswa dan lulusan, pada poin 3.2 jenis layanan pada mahasiswa, yang salah satunya adalah bimbingan karier. Di samping itu setiap perguruan tinggi idealnya memang harus memiliki pusat informasi karier atau Carier Centre bagi mahasiswa, sehingga mahasiswa bisa mengakses informasi sistem requirement, kompetensi yang harus dipersiapkan dan dibutuhkan oleh bidang pekerjaan, dan mendapatkan bimbingan terkait pilihan dan keputusan karier yang akan diambil setelah lulus atau setelah menyelesaikan studi.

Selanjutnya dengan munculnya Kerangka Kualifikasi Nasional Indonesia (KKNI), dimana setiap program studi harus menghasilkan learning outcomes atau profil lulusan yang jelas atau adanya relevansi antara latar belakang pendidikan dengan pekerjaan yang dijalani (Relevancy of Jobs). Tujuan ini tentu akan terwujud dengan baik jika program studi menyiapkan kompetensi lulusan dengan baik, artinya persiapan dilakukan tidak hanya dari kompetensi bidang saja, namun kompetensi dasar yang merupakan persyaratan bagi calon lulusan untuk dapat diterima pada pekerjaan tertentu. Kompetensi ini merupakan standar bagi

*Penulis adalah Dosen Jurusan Dakwah IAIN Bengkulu 
lulusan untuk dapat bersaing atau berkompetisi dalam memasuki bidang pekerjaan tertentu, sedangkan kompetensi bidang dibutuhkan setelah mahasiswa lulus seleksi kompetensi dasar atau setelah menempati pekerjaan. Namun kondisi ini tidak menjadi perhatian yang serius bagi beberapa perguruan tinggi untuk menyiapkan lulusannya dari segi kompetensi dasar maupun kompetensi bidang melalui bimbingan karier di perguruan tinggi, sehingga tidak jarang kita temui ketidak sesuaian latar belakang pendidikan dengan bidang pekerjaan, misalnya lulusan kebidanan bekerja di perbankan, atau lulusan perbankan bekerja sebagai tenaga pengajar di pendidikan anak usia dini, lulusan sarjana sosial bekerja sebagai security di lembaga swasta. dalam hal ini memang tidak ada yang salah namun, potensi dan kebermanfaatan ilmu yang ditempuh selama menjalani studi tentu tidak maksimal.

Berdasarkan hasil penelitian yang ditemukan Kramer, dkk terhadap mahasiswa Universitas Cornell ditemukan $48 \%$ mahasiswa laki-laki dan $61 \%$ mahasiswa perempuan mengalami masalah dalam pilihan dan perencanaan karier. Penelitian lain menemukan bahwa sebagian mahasiswa yang memasuki perguruan tinggi di Amerika menginginkan adanya pendampingan dalam perencanaan karier atau pilihan karier. Dari penelitian tersebut ditemukan betapa butuhnya mahasiswa terhadap pembimbingan (Assistance) terhadap karier yang akan dituju ${ }^{3}$. Tantangan yang akan dihadapi mahasiswa dalam menentukan karier, diantaranya adalah ketidakpastian karier, pengaksesan informasi dan program pengembangan karier, tantangan-tantangan ekonomi dan teknologi. Untuk mengantisipasi tantangantantangan ini perlu bagi perguruan tinggi untuk memberikan pelayanan yang optimal terhadap perkembangan karier mahasiswa. salah satunya dapat diwujudkan dengan adanya pusat informasi karier atau carrier center yang berfungsi untuk memberikan bimbingan karier bagi mahasiswa sebagai persiapan ke Dunia Kerja.

Disamping masalah ketidak sesuaian antara latar belakang pendidikan dengan bidang pekerjaan, masalah yang muncul terjadinya jumlah pengangguran yang cukup signifikan dikalangan sarjana. Berdasarkan Data dari Badan Pusat Statistik (BPS) tahun 2017 diperoleh angka untuk sarjana yang mengaggur sebanyak 856. 644 jiwa dari total 7.005.262 jiwa pengganguran, sekitar $10 \%$ penggangguran adalah sarjana, angka ini masih terbilang tinggi ${ }^{4}$. Banyak faktor yang menyebabkan tingkat pengganguran tersebut, diantaranya kurangnya lapangan pekerjaan, sedikitnya persentase lulusan yang mampu untuk menciptakan lapangan pekerjaan, kurangnya sumberdaya manusia (SDM) 
yang berkulialias, untuk dapat meminimalisir kondisi ini tentu perguruan tinggi harus memiliki semacam pusat bimbingan karier (carrier centre) sebagai unit atau lembaga yang berfungsi untuk memberikan berbagai informasi karier pada mahasiswa dan alumni. Artikel ini akan memaparkan informasi-informasi bimbingan karier yang dibutuhkan oleh mahasiswa tahun akhir, lulusan atau alumni untuk dapat membantu kesiapan mahasiswa dalam memasuki dunia kerja.

\section{Pembahasan}

\section{Sejarah Bimbingan Karier di} Perguruaruan Tinggi

Pelayanan bimbingan dan konseling di perguruan tinggi, khususnya bimbingan konseling karier, pada prinsipnya telah dilaksanakan sejak tahun 1981. Pelaksanaan layanan bimbingan dan konseling ini diawali dengan pelatihan dosen perguruan tinggi negeri di dua Fakultas Psikologi yaitu Universitas Indonesia dan Universitas Padjajaran selama tiga bulan. Dalam pelatihan tersebut masing-masing dosen perguruan tinggi telah menyusun program bimbingan dan konseling untuk perguruan tinggi masingmasing.

Pelaksanaannya belum seperti yang diharapkan, karena pimpinan perguruan tinggi ataupun pemerintah belum mampu memfasilitasi berdirinya biro atau pusat pelayanan bimbingan dan konseling. Suatu yang menggembirakan, beberapa IKIP waktu itu telah melaksanakannya termasuk IKIP Padang yang sekarang beralih nama menjadi Universitas Negeri Padang (UNP). Biro Bimbingan dan Konseling inilah yang menjadi cikal bakal berdirinya Unit Pelaksanaan Bimbingan dan Konseling (UPBK). Tahun 1996, UPBK berkembang dengan adanya Proyek Dirjen Dikti Depdikbud Student Support Services And Career Planning Development (3SCPD). Pelaksanaan di tingkat Departemen adalah Dosen PTN, khususnya dari IKIP Padang 5 . Proyek ini mengembangkan pelayanan Bimbingan dan Konseling di Perguruan Tinggi Negeri seIndonesia yang langsung melibatkan mahasiswa dengan berbagai jenis layanan bimbingan dan konseling. Sesuai dengan nama proyeknya, di samping mambantu masalah akademik mahasiswa, juga membantu rencana pengembangan karier mahasiswa. Tahun 2000-an proyek ini berakhir, pengembangan selanjutnya diserahkan kepada perguruan tinggi masing-masing.

Sedangkan untuk di Amerika Serikat, Bimbingan karier telah dilaksanakan sekitar 20 tahun yang lalu, yang berfungsi untuk mendesain beraneka program komputer sebagai alat bantu dalam memperoleh informasi karier di masa depan, selain itu di pusat bimbingan 
karier ini tersedia bahan informasi karier dalam bentuk terbitan atau cetakan, audio visual dan program komputer, serta alat tes atau asessment untuk mengukur minat dan bakat.

\section{Pengertian}

\section{Bimbingan Karier}

Bimbingan Karier adalah

bimbingan dalam mempersiapkan diri menghadapi dunia kerja, dalam memilih lapangan kerja atau jabatan atau profesi tertentu serta membekali diri supaya siap memangku jabatan itu, dan dalam menyesuaikan diri dengan berbagai tuntutan dari lapangan pekerjaan yang dimasuki. Bimbingan karier juga dapat dipakai sebagai sarana pemenuhan kebutuhan perkembangan individu yang harus dilihat sebagai bagian integral dari program pendidikan yang diintegrasikan dalam setiap pengalaman belajar bidang studi.

Bimbingan karier adalah suatu proses bantuan, layanan dan pendekatan terhadap individu, agar individu yang bersangkutan dapat mengenal dirinya, memahami dirinya, dan mengenal dunia kerja merencankan masa depan dengan bentuk kehidupan yang diharapkan untuk menentukan pilihan dan mengambil suatu keputusan bahwa keputusannya tersebut adalah paling tepat sesuai dengan keadaan dirinya dihubungkan dengan persyaratan- persyaratan dan tunutan pekerjaan atau karier yang dipilihnya. Selanjutnya menurut Herr bimbingan karier adalah suatu perangkat, lebih tepatnya suatu program yang sistematik, proses, teknik, atau layanan yang dimaksudkan untuk membantu individu memahami dan berbuat atas dasar pengenalan diri dan pengenalan kesempatan-kesempatan dalam pekerjaan, pendidikan, dan waktu luang, serta mengembangkan keterampilanketerampilan mengambil keputusan sehingga yang bersangkutan dapat menciptakan dan mengelola perkembangan kariernya ${ }^{6}$.

Menurut Winkels dan Sri Astuti, bimbingan karier merupakan bimbingan dalam mempersiapkan diri menghadapi dunia kerja, dalam memilih lapangan kerja atau jabatan atau profesi tertentu serta membekali diri supaya siap memangku jabatan itu, dan dalam menyesuaikan diri dengan berbagai tuntutan dari lapanan pekerjaan yang dimasuki ${ }^{7}$.

Dari uraian di atas dapat disimpulkan bahwa bimbingan karier adalah proses bantuan terhadap individu agar dapat mengenal dan memahami dirinya, mengenal dunia kerjanya, mengembangkan masa depan sesuai dengan bentuk kehidupan yang diharapkannya, mampu menentukan dan mengambil keputusan secara tepat dan bertanggung jawab. 


\section{Komponen dan unsur Bimbingan} Karier

Sejatinya bimbingan karier sudah diberikan sejak jenjang pendidikan menengah pertama sampai perguruan tinggi, rangkaian pemilihan sekolah dan jurusan sampai pada pemilihan prodi di perguruan tinggi merupakan rangkaian dan tahapan dari bimbingan karier, adapun unsur-unsur yang terlibat dalam proses bimbingan karier adalah:

a. Konselor atau pengajar, konsultan

untuk jejang pendidikan menengah, biasanya bimbingan karier diberikan oleh konselor sekolah, sedangkan untuk tingkat perguruan tinggi, idealnya bimbingan karier diberikan oleh tenaga konselor yang telah memiliki lecensi Tes Psikologis, atau dapat juga dilakukan dengan bekerjasama dengan psikolog pada bidang assessment industri, serta dapat bekerjasama dengan bagian personalia perusahaan atau bidang HRD (Human Resources Departement) untuk dapat berbagi materi tentang kebutuhan dunia kerja.

b. Konseli atau peserta layanan

Adapun yang menjadi peserta dalam bimbingan karier dapat sifatnya kelompok maupun perorangan, yang dapat dilakukan dengan metode layanan klasikal, individu, maupun kelompok, sesuai dengan kebutuhan. c. Materi bimbingan karier

Materi bimbingan karier juga disesuiakan dengan tingkatan atau jenjang sasaran layanan bimbingan. serta sesuai dengan kompetensi apa yang harus atau dibutuhkan oleh dunia kerja.

\section{Pentingnya Bimbingan Karier di}

\section{Perguruan Tinggi}

Urgensi Bimbingan Karier merujuk pada tujuan dari dilaksanakannya bimbingan karier itu sendiri, yang pada dasarnya berawal dari kebutuhan peserta layanan terhadap berbagai informasi terkait karier yang akan dijalani, untuk tahapan yang termasuk dalam perkembangan dan pereode tahapan karier individu adalah mengambil keputusan untuk memilih pekerjaan tertentu. Sebagaimana telah dijelaskan sebelumnya bahwa karier merupakan proses yang lama dalam rentang kehidupan seseorang, atau dapat dikatakan bahwa karier berlangsung sepanjang rentang kehidupan seseorang, sebagaimana pendapat yang dikemukakan oleh Muri Yusuf bahwa karier merupakan urutan posisi atau pekerjaan utama yang diduduki seseorang yang prosesnya berlangsung mulai dari remaja sampai pensiun. tahapan karier itusendiri dapat dibagi menjadi tiga tahapan utama yaitu; Pre-Okupasi (Proses belajar pada jenjang pendidikan, mulai dari Sekolah Dasar hingga Perguruan Tinggi), Okupasi 
(pereode bekerja atau masa bekerja), dan Post-Okupasi (masa pensiun). ${ }^{8}$

Berdasarkan tahapan di atas, mahasiswa sebagai mahasiswa tahun akhir sebagai individu yang belajar di perguruan tinggi berada pada masa pre-okupasi, atau dapat dikatakan masa transisi menjelang pereode okupasi, karena perguruan tinggi merupakan jenjang pendidikan tertinggi dalam tahapan pendidikan seseorang. Pada masa inilah pereode yang sangat penting dalam memahami berbagai informasi terkait dengan pekerjaan yang akan ditempati. Prayitno mengungkapkan bahwa saat-saat transisi dari dunia pendidikan ke dunia kerja sering merupakan masa yang sulit bagi banyak orang muda, kesulitan itu tidak hanya terletak pada kemampuan mendapatkan pekerjaan yang cocok, namun penyesuaian diri pada pekerjaan yang baru dimasuki serta pengembangan diri selanjutnya ${ }^{9}$.

Transisi dari proses belajar ke dunia kerja yang sebenarnya membutuhkan banyak persipan diri, mulai dari memahami kemampuan diri, yang idealnya telah dikenali sejak berlangsungnya proses pendidikan menengah atas, yaitu setelah berlangsungnya proses peminatan dan penempatan penyaluran pada jurusan yang sesuai dengan hasil berbagai instrumen tes terkait dengan kemampuan yang dimiliki oleh seseorang, namun pada perode ini sering terjadi berbagai kesenjangan, ketidaktahuan akan kemampuan diri, karena dalam proses pre-okupasi sudah mengalami berbagai permasalahan, yang berawal dari pemilihan jurusan di sekolah menengah yang tidak sesuai dengan minat dan bakat, berlanjut pada pemilihan program studi yang dimasuki di perguruan tinggi kecenderungan ikut-ikutan teman, dan adanya tuntutan dari keluarga, sehingga setelah proses tahapan penyelesaian studi mulai binggung dan kesulitan mengarahkan diri untuk memilih berbagai pekerjaaan. untuk itulah sangat penting bimbingan karier di perguruan tinggi dilakukan terutama untuk membantu mahasiswa tahun akhir setelah menyelesaikan studinya, sehingga tidak terlalu lama berada pada masa tunggu dalam mendapatkan pekerjaan.

Selain itu bimbingan karier bertujuan untuk membantu mahasiswa memahami perencanaan karier dan proses penempatan setelah mereka menamatkan perguruan tinggi, dengan adanya bimbingan karier ini dapat membantu mahasiswa dalam mempersiapakan kompetensi yang harus dimiliki, baik kompetensi akademik maupun non akademik yang sesuai dengan tuntutan dunia kerja. Fungsi utama dari bimbingan karier bagi mahasiswa tahun akhir khususnya, alumni dan lulusan adalah sebagai berikut: 
a. Bimbingan karier dapat membantu dalam memilih bidang pelayanan utama (kebutuhan untuk mendapatkan informasi tentang seminar karier dengan melibatkan lembaga penerima tenaga kerja (Stakeholder) dengan mahasiswa dan Perguruan tinggi. Konselor menginformasikan berbagai jenis dan persyaratan berbagai macam pekerjaan yang mungkin dapat dilamar mahasiswa setelah tamat kuliah. Meskipun mahasiswa zaman berada pada zaman digital, namun faktanya masih banyak mahasiswa yang kebingungan dalam mendapatkan informasi yang valid terkait informasi pekerjaan, disamping itu minimnya sikap proaktif dari mahasiswa untuk mencari informasi yang update terkiat lowongan kerja serta ketidaksiapan dalam menyesuiakan dengan tututan bidang pekerjaan yang ada, misalnya terkait dengan persyaratan kemampuan berbahasa asing baik aktif maupun pasif. Selain seminar tentang karier pameran-pameran karier juga merupakan ajang penting yang mestinya diikuti oleh masiswa atau lulusan, sehingga akan menambah berbagai informasi terkait pekerjaan-pekerjaan yang memungkinkan untuk dimasuki. sehingga dengan adanya berbagai informasi terkait karier ini mahasiswa akan lebih siap dalam menyesuaikan diri dan menambah skill yang dibutuhkan dengan tuntutan pekerjaan atau skill yang dibutuhkan oleh bidang pekerjaan tertentu, yang terkadang sangat jauh dengan bidang pendidikan yang telah dilewati, bahkan untuk tahapan awal recruitmen biasanya perusahaan ataupun lembaga instansi tertentu membutuhkan skill dasar, misalnya kemampuan komunikasi, penampilan atau perpormance, sedangkan untuk kemampuan bidang yang sesuai dengna bidang studi di perguruan tinggi adalah skill kedua yang harus dikuasi setelah berhasil lolos pada tahap pertama.

b. Bimbingan karier dapat membantu dalam penilaian diri dan analisis diri (hasil tes kemampuan dasar atau potensi tes akademik, kebutuhan untuk mendapatkan assessment sebagai umpan balik (feedback) dalam pemahaman dirinya). sertelah memberikan informasi berbagai seminar, dan pameran karier tertentu, bimbingan karier juga berfungsi dalam membantu mahasiswa dalam mengidentifikasi kemampuan diri melalui berbagai instrumen yang dimaliki, tes potensi diri yang merupakan gambaran tentang kemampuan dasar yang dimiliki individu, setiap tahapan perekrutan pegawai ataupun karyawan pada beberapa instansi atau perusahaan tes ini biasanya selalu dilakukan, yang berfungsi untuk melakukan identifikasi pada para pelamar, serta digunakan sebagaai bahan 
pertimbangan dalama menempatkan individu pada bidang pekerjaan tertentu.

c. Bimbingan karier dapat membantu dalam memahami dunia karier (kebutuhan untuk memiliki wawasan, pengetahuan tentang prosfek atau kemungkinan pasar kerja yang dapat menerima sesuai dengan kompetensi yang dimiliki, lowongan pekerjaan, penulisan surat lamaran dan Curiculum Vitae yang sesuai dengan kompetensi yang dibutuhkan oleh instansi atau lembaga kerja, materi tes (tes dasar maupun tes wawancara), kebutuhan untuk mendapatkan informasi terkait bursa kerja dan pertemuan-pertemuan karier yang banyak dilakukan pengusaha). persyaratan administrasi yang harus disiapkan terlebih dahulu dalam mengikuti tahapan recruitmen adalah menyipakan administrasi, surat lamaran, yang dilengkapi dengan berkas ijazah, serta pengharagaa-penghargaan berupa sertifikat yang pernah didapatkan serta Curriculum Vitae, yang terkadang terlihat sederhana, namun ini juga dapat dijadikan standar dalam menilai seseorang. Informasi terkiat berkas-berkas lamaran yang harus disiapkan ini juga sudah tersedia contohcontoh formatnya di media internet, namun para pelamar juga harus perlu mempelajari berbagai kekhususannya, misalnya ada beberapa bidang pekerjaan yang mengahruskan untuk pelamar menulis lamaran dengan menggunakan tulisan tangan, yang memiliki makna psikologis terntu dalam melakukan penilaian pada individu. selanjutnya dalama proses wawancara dan interviu yang biasanya dilakukan setelah proses akhir dari sisitem recruitmen mulaai dari tahapan adminisitrasi, tes kemampuan dasar dan bidang dilanjutkan dengan proses wawancara. Pada tahapan ini juga banyak hal-hal yang penting yang harus disiapkan, misalnya bahasa yang harus dikuasi pada saat wawancara, teknik yang baik supaya sesuai dengan kretria penilaian yang sudah menjadi standar dalam tahapan tes, etika sopan santun yang menjadi catatatan penting dalam proses wawancara juga menjadi bagian yang penting untuk dipelajari oleh pelamar.

d. Bimbingan karier dapat membantu dalam mengambil keputusan (kebutuhan untuk diarahkan dalam memilih karier atau bidang pekerjaan yang tepat untuk pengembangan potensi). ketepatan seseorang dalam mengambil keputusan dalam memilih bidang pekerjaan yang akan dijalaniny sangat penting, karena ketepatan dalam menentukan pillihan akan sangat berpengaruh terhadap kesuksesan seseorang dalam menjalani dan mengembangkan diri dalam dunia kerja yang ditempatinya. kesalahan dalam mengambil keputusan karier ini juga tidak 
hanya menimbulkan kerugian pada diri individu yang bersangkutan, namun juga akan berdampak pada instansi, perusahaan atau lembaga tempat individu tersebut bekerja, misalnya terjadinya penuruanan kinerja, angka resign yang meningkat, hal ini tentu menuntut perusahan atau bidang pekerjaan tersebut untuk merecruit ulang para pegawainya. Individu yang telah salah dalam mengambil keputusna karier akan kesulitan dalam menyusaikan diri dengan bidang pekerjaan yang telah ditempatinya, kesulitan dalam mengembnagkan diri, kehilangan semangat kerja yang berujung pada terjadinya resign atau pengunduran diri. Bimbingan karier dapat membantu menginformasikan kepada mahasiswa dalam memilih dan mengmabil keputusan karier sesuai dengan minat bakat yang dimiliki, kemungkinan-kemunginan yang akan didapatkan dari pekerjaan yang dimasuki dapat meningkatkan kemampuan dan kompetensi diri sehingga akan bermanfaat baik bagi instansi atau lembaga perusahaan yang dimasuki, untuk dapat membantu pengambilan keputusan karier yang tepat, perlu dilakukan berbagai pertimbangan yang lebih matang. Penganalisan kopentensi dan kemampuan diri secara tepat, sehingga tuntutan yang diinginkan dari pekerjaan yang hendak dimasuki dapat sesuai dengan kemampuan individu tersebut. Kelebihan dan kekurang an dari pekerjaan yang akan dimasuki perlu dilakukan pembicaraan dan penganalisisan dengan baik, sehingga pada saat memutuskan pilihan benar-benar dilakukan dengan tepat.

e. Bimbingan karier dapat membantu mahasiswa dalam memasuki dunia kerja (kebutuhan tentang etika dan budaya kerja, kesempatan dalam pengembangan diri, dukungan, kesesuaian antara posisi kerja yang ditempati dengan kompetensi yang dimiliki). Kesiapan diri yang baik dalam memasuki dunia kerja sangat penting, mulai dari tahapan mengikuti recruitmen sampai pada tahapan penempatan pada bidang tertentu dari pekerjaan, persiapan yang dilakukan tidak hanya menyiapkan kelengkapan adminitrasi saja seperti berkas lamaran, serta kesiapan dari segi pendidikan namun, budaya kerja dan etika kerja dari bidang pekerjaan yang dimasuki sangat penting untuk dipersipkan Banyak individu yang resign dari perusahanan atau bidang pekerjaan tertentu karena ketidakmampuan dalam menyesuiakan diri dengan lingkungan kerja yang dimasuki, rekan kerja, atasan dan budaya kerja atau tuntutan jam kerja yang harus dipenuhi, sehingga rentan untuk stres, dan penurunan semangat atau motivasi kerja, dan akan berkorelasi dengan prestasi kerja yang buruk, untuk itu mahsiswa tahun akahir yang akan memasuki dunia kerja, perlu dibekali dengan wawasan tentang 
informasi tentang etika dan budaya kerja, sehingga akan lebih mudah untuk menyesuiakan diri dengan lingkungan kerja yang dimasuki. Materi bimbingan karier yang harus diberikan dalam menyiapkan seseorang untuk dapat memahami dan menyiapkan diri untuk masuk kedunia kerja dengan memahami etika dna budaya kerja yang ada adalah, dengan cara memberikan magang khusus pada mahasiswa untuk dapat mengidentifikasi berbagai budaya dan etika kerja dari pekerjaan yang dimasuki. dengan adanya magang ini teori-teori yang sudah didapatakan di perguruan tinggi baik yang berkaitan dengan studi yang ditempuh, maupun dengan keterampilan tambahan yang perlu dikuasai dapat lebih rill, artinya mahasiswa tidak hanya belajar teori, namun lebih ke fakta di lapangan. Setelah magang ini dilakukan hendaknya dibahas bersama apasaja yang mestinya dievaluasi dan ditindak lanjuti terkait kesiapan karier mahasiswa dalam memasuki dunia kerja dan menyesuikan diri dengan budaya kerja yang ada.

\section{Metode Bimbingan Karier di}

\section{Perguruan Tinggi}

Pusat informasi karier atau career centre, idelanya dimiliki oleh setiap perguruna tinggi, sebagai wadah pelaksanaan dari proses bimbingan karier mahasiswa, sebagaimana telah diuraikan pada bagian pendahuluan, bahwa bimbingan karier merupakan bagian yang terintgral dari layanan yang diberikan pada mahasiswa, dan menjadi salah satu poin penilaian dalam akreditasi perguruan tinggi. Adapun metode atau cara pelaksanaan dari bimbingan karier dapat dilaksanakan dengan metode sebagai berikut:

Pertama, Layanan Orientasi, bimbingan karier diaplikasikan dengan menggunakan format lapangan, mahasiswa diperkenalkan langsung dengan bidang-bidang pekerjaan tertentu dengan mengunjungi perusahaan, atau lembaga pekerjaan tertentu, dengan demikian mahasiswa dapat meilhat gambaran rill dari pekerjaan yang akan dimasuki, sebaiknya bidang-bidang pekerjaan yang sesuai dengan background pendidikan yang ditempuh mahasiswa. Program ini sebenarnya sudah terintegritas dalam kurikum, yaitu pada program magang ataupun PPL. untuk layanan orientasi dapat dilakukan pada lembagalembaga yang memang belum terdaftar di tempat magang sebelumnya. sehingga dapat menjadi pengalaman dan ilmu serta wawasan yang baru bagi para mahasiswa. kedua, layanan informasi, layanan ini sangat memmungkinkan untuk dilakukan dengan cara format klasikal maupun kelompok, diberikan berbagai informasi karier, seputar persiapan untuk memasuki bidang pekerjaan tertentu, sistem recruitmen, serta administrasi berkas yang 
harus disiapkan untuk melamar pekerjaan tertentu. Layanan informasi juga dapat dilengkapi dengan berbagai metode yang lain, yaitu dengan menggunakan media, website khusus bimbingan karier perguruan tinggi, yang menyediakan berbagai informasi seputar karier, informasi loker terupdate, dan ruang diskusi, yang dpaat dilakukan melalui group-group facebook, whatshap, dan email. selain itu dapat juga dibuat hari karier atau career day yang dapat dilakukan setahun satu kali atau sesuai dengna pereode wisudah mahasiswa, yang dapat dikolaborasikan dengan berbagai pameran dan seminar karier yang menyediakan stand-stand karier yang dilakukkan dengan cara bekerjasama dengan perusahaan, atau instansi tertentu. untuk informasi yang lebih kreatif seperti ini biasanya cenderung lebih diminati oleh mahasiswa, dibanding dengan metode ceramah. Ketiga, Layanan konseling individu, dengan layanan konseling individu ini, mahasiswa diberi ruang untuk lebih terbuka menyampaikan masalahnya, terutama terkait masalah karier misalnya masalah kebinggungan dan ketidaksiapan setelah tamat untuk bekerja dimana, adanya ketidaksesuaian antara keinginan orang tua dengan keinginan mahasiswa, atau orang tua yang cenderung menuntut anaknya agar bekerja di kampung setelah kuliah. sedangkan pekerjaan di luar daerah lebih menjanjikan. Keempat, layanan Bimbingan Kelompok, layanann ini dapat dikemas dengan topik tugas maupun bebas sesuai dengan kebutuhan mahasiswa, misalnya dengan mengakat topik-topik yang update terkait maslah kiat sukses mendapatkan pekerjaan secara cepat dalam masa tunggu setelah fresh graduate.

Pelaksanaan layanan akan lebih efektif jika didukung dengan kegiatan pendukung layanan, yaitu dapat dengan melakukan latihan tes psikologis, atau tes potensi akademik, sehingga mahsiswa akan lebih terampil dalam mengikuti tes yang sebenarnya, selain itu tampilan kepustakaan juga penting dilakukan untuk menambah pemahamanan dan informasi seputar masalah dan hal-hal yang terkait dengan pekerjaan atau karier, misalnya konselor bisa meminjamkan trik-trik sukses karier kepada mahasiswa apa saja yang harus dipersiapakan atau dapat juga menggunakan intrnet dengan cara dibimbing dan didampingi, sehingga masalah ketidakpahaman dapat dientaskan.

\section{Penutup}

Bimbingan karier sangat penting bagi mahasiswa dalam menyiapkan diri untuk memasuki dunia kerja, dengan adanya bekal, mereka dapat mempersiapkan diri sesuai dengan kebutuhan dunia kerja, sehingga kompetensi yang dimiliki dapat 
berkembang dengan baik, serta proses perkuliahan yang mereka dapatkan diperkuliahan selama ini akan lebih maksimal. selain itu dengan adanya bimbingan karier ini para mahasiswa tahun akhir, fresh graduate, para lulusan atau alumni yang sedang berada pada masa tunggu dalam mendapatkan pekerjaan akan lebih siap lagi, dan dapat meminimalisir berbagai masalah yang berhubungan dengan kebingungan dan ketidaksiapan dalam memasuki dunia kerja, setelah menyelesaikan studi atau setelah tamat kuliah, dengan adanya bimbingan karier diharapakan dapat menjadi salah satu jawabaan atas permasalahan ketidaksiapan mahasiswa dalam memasuki dunia kerja. Selanjutnya diharapkan juga dengan adanya bimbingan karier ini mahasiswa dapat memilih bidang pekerjaan yang sesuai dengan kualifikasi lulusan mereka, dengan demikian kebermanfaatan ilmu yang telah mereka jalani di bangku perkuliahan akan lebih maksimal dan bermakna.

\section{Endnote}

1 Panduan Pengisian Borang Akreditasi Perguruan Tinggi, 2014. Jakarta; BANPT.

${ }^{2}$ Edwin L. Herr, and Stenley H.Cramer. Career Guidance and Counseling Trough the Life Span, Systematic Approuches, New York, Harper Collins Publisher. 1996. hal. 293.

3 Agus Rianto. 2009. Sukses Belajar di Perguruan Tinggi. Padang: UNP Press. 2009. hal. 24

${ }^{4}$ Data Online Badan Pusat Statistik (BPS).

5 Panduan Pengembangan karir di perguruan Tinggi Student Support Services And

Career Planning Development (3SCPD. IKIP Padang. 1996. hal. 75

6 Herr, E.l and Cramer, S.H. Career Guiudance and counselling Through the life Span. Boston : Litte. Brown \& Company.1984. hal.300

${ }^{7}$ Winkels dan Sri Hastuti. Bimbingan dan Konseling di Intitusi Pendidikan. Jakarta: Gramedia. 2005. hal. 336

${ }^{8}$ A.Muri Yusuf. Konseling Karier Dalam Satuan Pendidikan dan Praktik Pribadi. Padang, Universitas Negeri Padang. 2006. hal.15

9 Prayitno, (2007). Peningkatan Potensi Mahasiswa. UNP Press: Padang. hal.84

10 Edwin L. Herr, and Stenley H.Cramer. Career Guidance and Counseling

Trough the Life Span, Systematic Approuches, New York, Harper Collins

Publisher. 1996. hal.321 